The University of Maine

\title{
DigitalCommons@UMaine
}

Earth Science Faculty Scholarship

Earth Sciences

7-1991

\section{Volcanic Ash from the 1362 A.D. Oræfajokull Eruption (Iceland) in the Greenland Ice Sheet}

\author{
J.M. Palais \\ K. Taylor \\ Paul Andrew Mayewski \\ University of Maine, paul.mayewski@maine.edu \\ P. Grootes
}

Follow this and additional works at: https://digitalcommons.library.umaine.edu/ers_facpub

Part of the Climate Commons, Glaciology Commons, and the Hydrology Commons

\section{Repository Citation}

Palais, J. M.; Taylor, K.; Mayewski, Paul Andrew; and Grootes, P., "Volcanic Ash from the 1362 A.D. Oræfajokull Eruption (Iceland) in the Greenland Ice Sheet" (1991). Earth Science Faculty Scholarship. 193.

https://digitalcommons.library.umaine.edu/ers_facpub/193 


\title{
VOLCANIC ASH FROM THE 1362 A.D. OREFAJOKULL ERUPTION (ICELAND) IN THE GREENLAND ICE SHEET
}

\author{
J.M. Palais ${ }^{1}$, K. Taylor ${ }^{2}$, P.A. Mayewski ${ }^{1}$ and P. Grootes ${ }^{3}$
}

\begin{abstract}
A continuous record of electrical conductivity measurements (ECM) was made on site during the drilling of a $200 \mathrm{~m}$ ice core at Summit, Greenland and was used to identify horizons in the ice that might be linked to volcanic eruptions. In one detailed section that we studied a large peak in the number of particles, two orders of magnitude above the background, was measured. The particle peak was not associated with an ECM peak, however. The particles were identified as volcanic ash on the basis of both particle morphology and chemical composition. The ash composition suggests an explosive rhyolitic eruption and is believed to have originatedfrom Oræfajokull in Iceland in 1362 A.D.
\end{abstract}

\section{Introduction}

Previous work by Hammer $(1977,1984)$ has demonstrated that elevated levels of electrical conductivity (ECM) in ice cores are usually due to the presence of acids (primarily $\mathrm{H}_{2} \mathrm{SO}_{4}$ ) that are associated with volcanic fallout. Except for recent work by Ram et al.. (1991) on deep ice core samples from the Dye 3 core and studies of surface snow related to the $1982 \mathrm{El}$ Chichon eruption by De Angelis et al.(1985), no volcanic ash has ever been identified in an ice core recovered in Greenland. Palais et al.(1990) identified volcanic ash in ice core samples from the South Pole which were selected on the basis of electrical conductivity and sulfuric acid measurements. The Antarctic ash was believed to have originated from a number of globally significant volcanic eruptions.

\section{Sampling and Analysis}

In this study, we used the continuous record of electrical conductivity measured (ECM) on the first $200 \mathrm{~m}$ of the GISP2 ice core drilled in 1989 at Summit, Greenland $\left(72^{\circ} 35^{\prime} \mathrm{N}, 38^{\circ} 28^{\prime} \mathrm{W} ; 3210 \mathrm{~m}\right.$ ) (Figure 1) as part of the Greenland Ice Sheet Project 2 (GISP2) to identify sections for detailed examination. These sections were sampled at a frequency of 10 samples per year and were chosen because they contained either ECM peaks or lows, or because they were believed to be representative of average background conditions.

Microparticle analyses were performed with an Elzone $\mathrm{tm}^{\mathrm{m}}$ model 280 PC particle counter. The Elzonetm operates on the Coultertm principle and measures the equivalent spherical diameter of insoluble particles immersed in a dilute electrolyte solution. The Elzonetm separates the particles into size range channels from approximately 0.6 to $13 \mu \mathrm{m}$ when using a 30

1 Glacier Research Group, Univ.N.H., Durham, NH

2 Desert Research Institute, Univ.Nevada, Reno, NV

3 Quaternary Research Center, Univ. Wash., Seattle, WA

Copyright 1991 by the American Geophysical Union.

Paper number 91GL01557

0094-8534/91/91GL-01557\$3.00

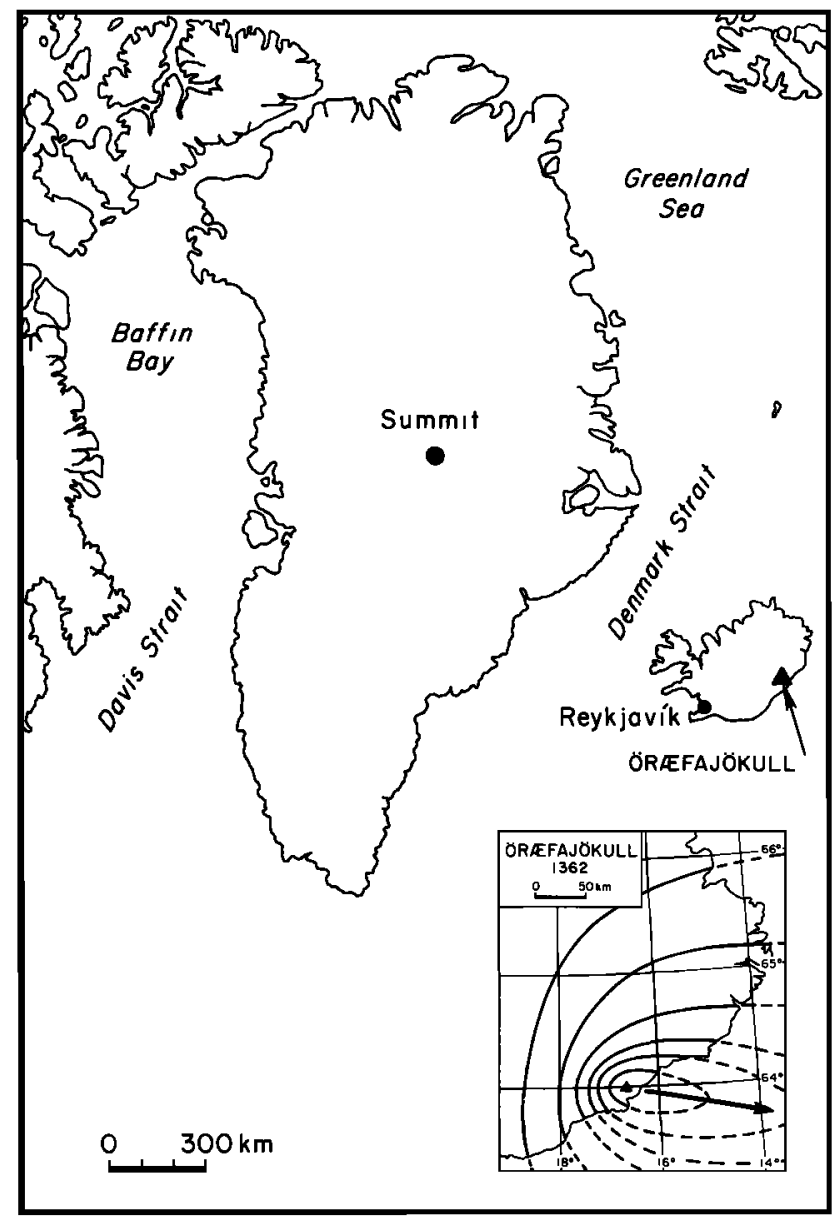

Fig. 1. Map of Greenland showing the GISP2 ice core drill site at Summit, Greenland and its geographical position relative to Iceland and the volcano Oraefajokull. Map inset shows the dispersal pattern of tephra about the volcano (after Thorarinsson, 1958).

um orifice tube. Each measurement reported here when using a $30 \mu \mathrm{m}$ orifice tube. Each measurement reported here represents the average of three analyses. The precision is typically from 5-10\% (Fiacco, 1991). Soluble anion and cation chemical analyses were performed by ion chromatography following techniques described by Mayewski et al.(1990).

\section{Results}

One of the sections which we chose to study, from 174-175 $\mathrm{m}$ (Figure 2), was picked to be representative of typical "background" conditions at this depth, although the ECM record also showed a fairly significant negative departure in the electrical conductivity (at $174.6 \mathrm{~m}$ ) which interested us because we thought it could be due to volcanic dust which had neutralized the background acidity of the ice. Detailed microparticle analyses of this section led to the 


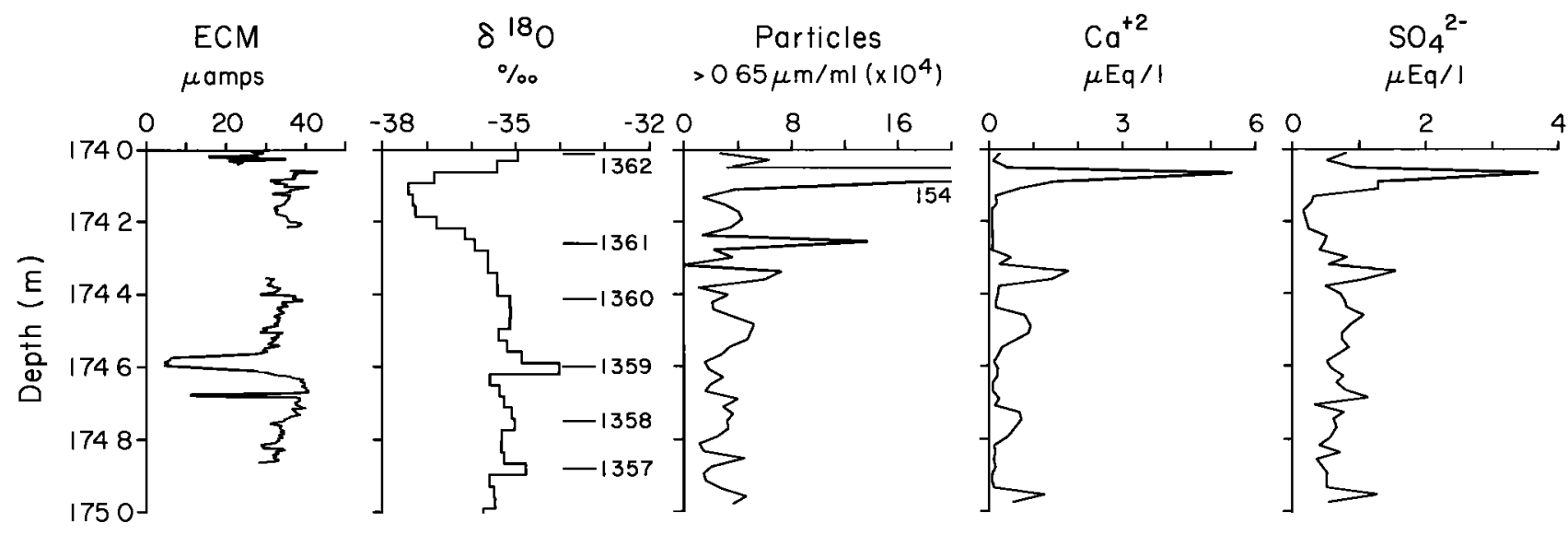

Fig. 2. ECM, oxygen-isotopes, particle number concentration, calcium and sulfate in a section of the GISP2 ice core from 174 to $175 \mathrm{~m}$.

discovery of a very large peak of particles at about $174.1 \mathrm{~m}$ in which the number concentration of particles in the size range from 0.65-12.88 $\mu \mathrm{m}$ was found to increase by two orders of magnitude from an average background of about $4.0 \times 104 / \mathrm{ml}$ to a peak value of about $1.6 \times 10^{6} / \mathrm{ml}$. This is the largest concentration of particles in the entire $200 \mathrm{~m}$ of core analysed so far. The estimated age of this layer is 1362 A.D. according to the current dating scheme derived from interpretation of detailed oxygen-isotope measurements on the GISP2 core (P. Grootes, unpublished data, 1991).

The size distribution of particles in this core section showed the preserice of a significant number of large particles as large as $25 \mu \mathrm{m}$ (in typical background samples particles are rarely larger than $5 \mu \mathrm{m}$ ). This peak in particles also corresponded to peaks in $\mathrm{SO}_{4}{ }^{2-}, \mathrm{Ca}^{+2}$ and to a lesser extent $\mathrm{Na}^{+}, \mathrm{K}^{+}$, and $\mathrm{Mg}^{+2}$.

The two samples from this section of core were filtered and a portion of the filter was studied by scanning electron microscope (SEM), for imaging and electron microprobe, for major element analyses. Figure 3 shows two examples of the particles extracted from this layer. The particles range in long dimension from less than $1 \mu \mathrm{m}$ up to $30 \mu \mathrm{m}$ and appear to be a mixture of fresh vesicular shard fragments and blocky ash with a small amount of sub-micron adhering dust.

Preliminary electron microprobe analyses of 8 glass shards from this layer gave an average composition which is shown in column 1 of Table 1 . These analyses suggest a silicic source magma and the shards are consistent with deposition from a plinian-type eruption cloud. The Oræfajokull eruption of 1362 A.D. was a major rhyolitic explosive eruption in Iceland that ejected $6.3 \mathrm{~km}^{3}$ of tephra $\left(2 \mathrm{~km}^{3}\right.$ D.R.E.) (Thorarinsson, 1958) (see Figure 1).

\section{Discussion}

According to Thorarinsson.(1958), the Oraefajokull eruption produced the biggest tephra layer in Iceland in historical times (since 870 A.D.) and the third greatest in Iceland during the Holocene (in terms of volume of tephra). The eruption is believed to have occurred in the middle of June, 1362 A.D. Palais and Sigurdsson (1989) analyzed the major element composition of glass inclusions and matrix glass in tephra from the 1362 A.D. Oræfajokull eruption (Table 1) and estimated the volatile degassing from this eruption. They estimated a total degassing of $3.4 \times 10^{6}$ metric tons of acid of which $11 \%$ was $\mathrm{H}_{2} \mathrm{SO}_{4}, 20 \%$ was
$\mathrm{HCl}$ and $69 \%$ was $\mathrm{HF}$. Unfortunately, there are no measurements of fluoride in the ice and the chloride concentrations in this section are only slightly elevated. In fact, emissions of $\mathrm{HCl}$ and $\mathrm{HF}$ are often not preserved in ice core layers since it is believed that they are easily scavenged from the atmosphere before reaching the polar regions (Legrand and Delmas, 1988).

Comparison of the major element composition of the ash particles from $174.1 \mathrm{~m}$ in the GISP2 core and analyses of glass from tephra samples known to be from Oraefajokull further suggest that the ash discovered in the GISP2 core is from this eruption (Table 1). Moreover, the coincidence in time of the eruption and the estimated age of this ash layer leaves little doubt that the volcanic ash discovered at $174.1 \mathrm{~m}$ in the GISP2 core is from the Oraefajokull eruption of 1362 A.D. It is also interesting to note that the position of the ash layer, relative to the oxygen-isotope profile, supports Thorarinsson's (1958) conclusion that the eruption took place in early summer (middle of June), 1362 A.D.

Very little is known about the transport distance of micron-sized volcanic ash away from a volcanic source. Empirical studies by Fisher (1964) suggest that undifferentiated tephra samples with a median diameter of about $30 \mu \mathrm{m}$ could be from a source as far as $800 \mathrm{~km}$ away depending on the density of the fragments, the force of the explosion, the height of the eruption column and the wind velocity to which the particles were subjected. Rose and Chesner (1987) found ash up to $55 \mu \mathrm{m}$ in a sample collected in India, $3100 \mathrm{~km}$ away from the source of the great Toba eruption (75 ka). Although the Toba eruption was three orders of magnitude larger (in terms of D.R.E.) than the 1362 Oræfajokull eruption, their work demonstrates the importance of studying distal, micron-sized ash from explosive volcanic eruptions.

The importance of long-range transport of atmospheric particulates has been highlighted recently by Palais et al. (1987), Betzer et al. (1988) and Ram and Gayley (1991). Palais et al. (1987) found glass shards up to $45 \mu \mathrm{m}$ in two tephra layers in East Antarctica which were believed to have traveled over $4000 \mathrm{~km}$ from their source in the South Sandwich Islands. Betzer et al. (1988) found "giant" (> 75 $\mu \mathrm{m})$ mineral aerosol particles, believed to be derived from China (Asian Dust), in atmospheric and water-column samples taken over the North Pacific Ocean, $10,000 \mathrm{~km}$ from their source. Finally, Ram and Gayley (1991) identified volcanic glass shards, up to $300 \mu \mathrm{m}$, in a section of Wisconsinan ice from the Dye 3 ice core in Greenland. Although a precise source was not given, the authors 

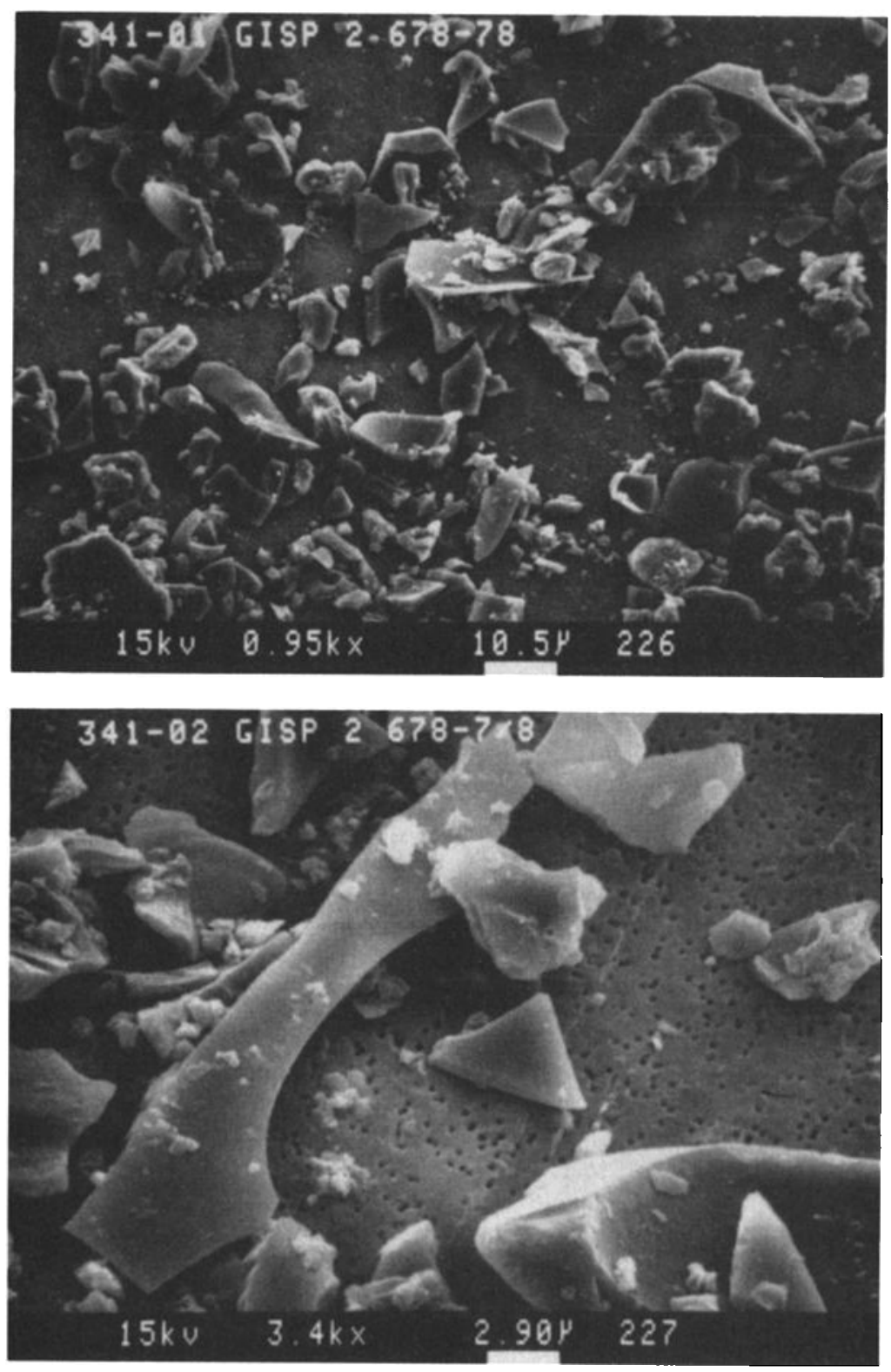

Fig. 3. Scanning electron micrographs of volcanic ash from a layer at $174.1 \mathrm{~m}$. Scale bar on lower right side of photograph.

speculated that the ash might be correlative with ash zone $Z_{2}$, observed by Ruddiman and Glover (1972) in sediment cores from the north Atlantic. The source of the ash is believed to be Icelandic and/or Jan Mayen volcanoes (Ram and Gayley, 1991).

Therefore it seems that given favorable conditions of atmospheric circulation/ transport (e.g. strong cyclonic storms and/or vigorous convective storms such as are common in the polar regions and the tropics, respectively), volcanic ash may be transported further than normally expected. Oraefajokull is about $1300 \mathrm{~km}$ from the Summit, Greenland coresite, well within the distance range given by the above examples.

\section{Summary}

The discovery of Orafajokull ash in the GISP2 core is significant because it is the first time that a discrete ash layer from a known volcanic eruption has been identified in the Greenland ice sheet. It is interesting to note that this layer cannot be identified on the basis of a peak in electrical conductivity (ECM). This is very likely due to a neutralization of the acidity by the abundant volcanic ash in this layer (Palais and Kyle, 1988). Further studies of dust samples believed to be volcanic ash are currently in progress. Positive identification of the source of these tephra should continue to help in the dating of the GISP2 core.

Acknowledgements. We thank Ursula Marvin, Beth Holmgren and Raymond Chuan, for assitance with the electron microprobe and SEM analyses. We also thank Sallie Whitlow, Chris Buck and Doug Barrett for the anion and cation analyses. Travis Salig assisted with the oxygen-isotope analyses and data reduction. This work was supported by the Division of Polar Programs, National Science Foundation. 
Table 1. Major element composition of volcanic ash from $174.1 \mathrm{~m}$ in the GISP2 ice core compared with analyses of tephra from the 1362 A.D. Orafajokull eruption.

\begin{tabular}{cccc}
\hline Sample & 1 & 2 & 3 \\
\hline $\mathbf{n}$ & 8 & 4 & - \\
Oxides & & & \\
$\mathrm{SiO} 2$ & $76.92(2.29) \dagger$ & $73.07(0.94)$ & 70.14 \\
$\mathrm{TiO} 2$ & $0.25(0.04)$ & $0.27(0.02)$ & 0.32 \\
$\mathrm{Al2O} 3$ & $13.23(0.72)$ & $12.9(0.29)$ & 13.28 \\
$\mathrm{FeO} *$ & $3.31(0.57)$ & $3.11(0.25)$ & 3.98 \\
$\mathrm{MnO}$ & $0.05((0.04)$ & $0.02(0.02)$ & 0.11 \\
$\mathrm{MgO}$ & $0.06(0.05)$ & $0.01(0.01)$ & 0.02 \\
$\mathrm{CaO}$ & $0.76(0.26)$ & $1.01(0.07)$ & 1.26 \\
$\mathrm{Na} 2 \mathrm{O}$ & $4.28(2.93)$ & $5.71(0.63)$ & 5.83 \\
$\mathrm{~K} 2 \mathrm{O}$ & $1.15(0.56)$ & $3.61(0.16)$ & 3.38 \\
\hline
\end{tabular}

1 Glass shards from $174.1 \mathrm{~m}$ in the GISP2 ice core. Analyses performed on a JEOL 733 Superprobe following procedures of Lindstrom et al. (1989).

2 Average composition of matrix glass in rhyolitic tephra fall from Oræfajokull 1362 A.D. eruption (Palais and Sigurdsson, 1989).

3 Grey-white pumice from the 1362 eruption collected by J. Jonsson at Sandfell in Orafi. (Thorarinsson, 1958). FeO+Fe2O3 calculated as $\mathrm{Fe} 2 \mathrm{O} 3$.

$\dagger=1$ standard deviation

* FeO, total $\mathrm{Fe}$ as $\mathrm{FeO}$

$\mathrm{n}=$ number of analyses.

\section{References}

Betzer, P.R., K.L. Carder, R.A. Duce, J.T. Merrill, N.W. Tindale, M. Uematsu, D.K. Costello, R.W. Young, R.A. Feely, J.A. Breland, R.E. Bernstein, and A.M. Greco, Long-range transport of giant mineral aerosol particles, Nature, 336, 568-571, 1988.

De Angelis, M., L. Fehrenbach, C.C. Jehanno, and M. Maurette, Micrometre-sized volcanic glasses in polar ices and snows, Nature, 317, 52-54, 1985.

Fiacco, R.J., Microparticles as a paleovolcanic indicator in the 1989 GISP2 firn and ice core, M.S. thesis, 138 pp.,University of N.H., Durham, N.H., May 1991.

Fisher, R.V., Maximum size, median diameter, and sorting of tephra, Jour. Geophys, Res., 69, 341-355, 1964.

Hammer, C.U., Past volcanism revealed by Greenland ice sheet impurities, Nature, 270, 482-486, 1977.
Hammer, C.U., Traces of Icelandic eruptions in the Greenland ice sheet, Jokull, 34, 51-65, 1984.

Lindstrom, M.M., U.B. Marvin and D.W. Mittlefehldt, Apollo $15 \mathrm{Mg}$ - and Fe-Norites: A redefinition of the Mg-suite differentiation trend, Proc. Lunar Planet. Sci. Conf. 19th , 245-254, 1989.

Legrand, M.R. and R.J. Delmas, Formation of $\mathrm{HCl}$ in the Antarctic atmosphere, Jour. Geophys. Res, 93, 7153-7168, 1988.

Mayewski, P.A., M.J. Spencer, M.S.Twickler, and S. Whitlow, A glaciochemical survey of the Summit region, Greenland, Annals Glaciol., 14, 186-190, 1990.

Palais, J.M., S. Kirchner, and R.J. Delmas, Identification of some global volcanic horizons by major element analysis of fine ash in Antarctic ice, Annals Glaciol, 14, 216-220, 1990.

Palais, J.M. and H. Sigurdsson, Petrologic evidence of volatile emissions from major historic and pre-historic volcanic eruptions, AGU Monogr.,52, 31-53, 1989.

Palais, J.M.and P.R. Kyle, Chemical composition of ice containing tephra layers in the Byrd Station ice core, Antarctica, Quat. Res, 30, 315-330, 1988.

Palais, J.M., P.R. Kyle, E. Mosley-Thompson, and E. Thomas, Correlation of a 3,200 year old tephra in ice cores from Vostok and South Pole Stations, Antarctica, Geophys. Res. Lett. 14, 804-807, 1987.

Ram, M. and R.I. Gayley, Long-range transport of volcanic ash to the Greenland ice sheet, Nature, 349, 401-404, 1991.

Rose, W.I. and C.A. Chesner, Dispersal of ash in the great Toba eruption, $75 \mathrm{ka}$, Geology, 15, 913-917, 1987.

Ruddiman, W.F. and L.K. Glover, Vertical mixing of ice-rafted volcanic ash in North Atlantic sediments, Geol. Soc.Am. Bull., 83, 2817-2836, 1972.

Thorarinsson, S., The Oræfajokull eruption of 1362, Act. nat. islandica. Reykjavik, II, 1958.

Pieter Grootes, Quaternary Isotope Laboratory, University of Washington, Mail Stop AJ-20, Seattle, Washington, 98195.

Paul A. Mayewski and Julie M. Palais, Glacier Research

Group, University of New Hampshire, Institute for the

Study of Earth. Oceans, and Space, Durham, New

Hampshire, 03824.

Kendrick Taylor, Water Resources Center, Desert Research Institute, Box 60220, Reno, Nevada, 89506-0220.

(Received: April 18, 1991; accepted: May 14, 1991.) 